\title{
The role of sexual education in preschool mental health care
}

\author{
Oksana Los \\ Kherson State University, Kherson, Ukraine
}

\begin{abstract}
.
1. The article is devoted to the problem of sexual education in preschool childhood, the author describes the psychological aspects of sexual development of a person in preschool age, discusses in detail the periods of formation of sexual identity, criteria of mental health, the importance of sexual education in the harmonious development of the personality of the child.

2. The development of new, more meaningful activities in the preschool childhood promotes the development of deeper and more stable emotions, connected not only with loved ones, but also with distant goals, not only with those objects that the child perceives, but also with those that he imagines. Activity generates, first and foremost, positive emotions, its purpose, the meaning it acquires for the child, and the very process of its fulfillment. Social emotions (likes, dislikes, preferences, etc.) are intensively developing. Intellectual emotions arise. In the process of communicating a child with adults, its moral feelings are formed. Manifestations of self-esteem are varied: both self-esteem and a sense of shame and unease develop. During the preschool childhood, the deepest layers of the psyche are laid and formed, which affect the further development of the individual.
\end{abstract}

3. Gender differentiation is most intimately woven into the canvas of this period. Children need to know their bodies to maintain their health. At preschool age, they are interested in their own bodies. Interest in one's own body is evident from birth. With age, the child freely distinguishes and correctly names the organs and parts of his body: eyes, tongue, lips, teeth, ears, hair; head, neck; torso - back, abdomen; hands and feet with fingers.

4. Interested in acting on their own experience. Even before the age of three, the child makes a "discovery" - shows where her eyes, ears, mouth, nose, tongue, teeth. He calls his actions: "I see," "I hear," "I said," etc. Parents and caregivers should remember that satisfying a child's interest in their own body is a major need. It is known that the unmet needs of the child cause suffering, and frequent suffering leads to the emergence of "destructive" emotions of anger, anger, aggression. They destroy the child itself (and the psyche, health in general), and its relationship with the environment. And from the experience gained during the preschool years, the child depends to a great extent on the optimist or pessimist, how much he or she will believe in his / her powers, and therefore how he / she will be able to overcome ordinary difficulties of life, resist obstacles, temptations, etc.

Key words: preschool child, emotional-volitional sphere, sexual development, age-related periodization of mental development, mental health criteria.

\section{Література:}


1. Исаев Д.Н., Каган В.Е. Половое воспитание детей: Медикопсихологические аспекты. Изд. 2-е, перераб. и доп. Ленинград: Медицина, 1988. 360 с.

2. Калуга В.Ф. Приречена сексуальністю. Проблема ідентичності людини 3 огляду на її сексуальну природу. Ніжин: Видавець ПП Лисенко М.М., 2011. 488 c.

3. Лохвіцька Л.В. Програма 3 основ здоров'я та безпеки життєдіяльності дітей дошкільного віку «Про себе треба знати, про себе треба дбати». Тернопіль : Мандрівець, 2014. 120 с.

4. Психологічне здоров’я дошкільників. Уклад. Т.І. Прищепа. Харків: Вид. група «Основа», 2010. 239с.

5. Родомицька Н., Романюк О., Сова Л. Гендерне виховання в ДНЗ. Київ: «Вид.група «Шкільний світ», 2018. 144 с.

6. Ткалич М. Г. Гендерна психологія: Навч. посіб. Київ: Академвидав, 2001. 248 c. 